\title{
Comentário:
}

\section{A VAIDADE DO CONHECIMENTO}

Marco Sabatini $^{1}$

Referência do artigo comentado: TOLEDO, R. O. Uma questão de vaidade: relaçóes entre Nietzsche e Mandeville. Trans/Form/Açáo: revista de filosofia da Unesp, v. 44, n. 1, p. 357-380, 2021.

No prólogo de Para a genealogia da moral, Nietzsche (1998) afirma que os "homens de conhecimento" - aqueles que acreditam investigar o mundo e descobrir suas verdades mais sólidas e secretas - sequer conhecem a si próprios. Como em todos os seus livros publicados, cada palavra e cada frase foram cuidadosamente planejadas e articulam-se por entre questionamentos refinados e complexos. Essa afirmação poderia, por exemplo, remeter-se diretamente a Sócrates e aos desdobramentos filosóficos de suas famosas conversas e inquiriçóes. Tais diálogos tendiam a criar, entre tantos desconfortos, a constatação de que aqueles que pensavam saber algo sobre determinado tema, na verdade, pouco ou nada sabiam sobre ele. Ora, percorreriam, entáo, os filósofos e pensadores contemporâneos de Nietzsche nas mesmas sendas que os opositores de Sócrates trilharam? Teriam aprendido pouco com a filosofia socrática e, na ânsia de consumar a racionalidade, aparentavam-se à argumentação sofística da antiguidade?

1 Programa de Pós-Doutorado em Educação da Universidade Federal de São Paulo, São Paulo, SP Brasil. (D) https://orcid.org/0000-0003-4757-3220 E-mail: marco_rsabatini@hotmail.com

https://doi.org/10.1590/0101-3173.2021.v44n1.28.p381

\section{(i)}


A partir desse polêmico mote, Nietzsche enuncia uma nova exigência: "[...] necessitamos de uma crítica dos valores morais, o próprio valor desses valores deverá ser colocado em questão [...]” (NIETZSCHE, GM, Prólogo, \$6 [1998, p. 12]). Para um leitor desavisado, a audácia desse projeto pode apresentar-se despropositada, não "apenas" por suspender a confiança em toda a filosofia e ciência humanas, mas, também, por indicar tão imenso empreendimento sem muitas explicações. Nietzsche trabalhou, no entanto, arduamente essa tese. Desde seus escritos filológicos, pensava os valores e costumes, comparandoos entre os diferentes tempos e culturas. Em suas obras Humano, demasiado Humano (v. I e II), Aurora e A gaia ciência, essa "vontade" incidente contra opinióes solidificadas e, muitas vezes, preconceituosas se exprimiu com força e beleza. Ela pronunciava uma cogitaçáo indigesta para quem detinha o poder sobre a verdade, afinal, insistia em perguntar, como bem expressou posteriormente, em Além de bem e mal: "Certo, queremos a verdade: mas por que não, de preferência, a inverdade? Ou a incerteza? Ou mesmo a insciência? - $\mathrm{O}$ problema do valor da verdade apresentou-se à nossa frente - ou fomos nós a nos apresentar diante dele?” (NIETZSCHE, BM, \$1 [2005, p. 09]).

Suspensas as estruturas tradicionais da filosofia, perguntas simples ressurgem: seríamos nós, filósofos e cientistas, seres cuja energia destinada ao conhecimento teria motivaçóes menos altivas do que comumente acreditamos? Ou seja, seriam as magníficas criaçóes filosóficas e artísticas produtos de nossa vaidade? $\mathrm{O}$ artigo de Ricardo de O. Toledo permite refletirmos sobre essa e várias outras hipóteses. Ao trazer Mandeville para o cenário nietzschiano, as virtudes são amotinadas e, como uma sutil jogada de xadrez, as peças parecem embaralhar o tabuleiro e confundir seus oponentes, os quais, não podendo distinguir a mera confusáo de um posicionamento estratégico, estão na iminência do derradeiro movimento de xeque-mate. Nietzsche não segue, porém, lógicas dualistas: "vencedor" e "perdedor", "vício" e "virtude", "bem" e "mal" são disjunçôes demasiado frágeis, perante seu pensamento. Talvez esse ponto seja um dos grandes elos com Mandeville, contra as tradicionais concepçóes da moral.

De acordo com Toledo (2021, p. 363), para o autor de A Fábula das Abelhas, "[...] as virtudes se resumem a meios socialmente persuasivos para a satisfação dos apetites egoístas sem que o indivíduo seja perturbado em excesso." Nessa perspectiva, o egoísmo é visto como uma energia motriz de cada indivíduo. Se fosse plenamente condenável, como acredita a concepção filosófica sobre os vícios, desde Aristóteles, as sociedades humanas viveriam 
na inércia e letargia, sem nada produzir e desenvolver. Por outro lado, isso significa que as atitudes e criaçóes humanas são realizadas apenas em lucro próprio, apesar de seus benéficos efeitos colaterais e de se armarem de discursos e adornos que fingem não ser o que são. Inúmeras relações poderiam ser feitas, com a vontade de poder de Nietzsche; mas a complexidade desse assunto precisaria de explicaçóes muito mais aprofundadas do que as indicaçóes aqui escritas, pois tal conceito nietzschiano não pode ser reduzido simplesmente ao egoísmo, nem a quaisquer outras concepçóes individualistas.

Essa importante ressalva não elimina, no entanto, a hipótese de que também o nosso conhecimento e toda a sua produção são movidos e guiados pela vaidade e pelo egoísmo, com fins utilitaristas objetivos dentro de nossa sociedade. Isso jamais reduziria o valor do conhecimento, independentemente da perspectiva. Contudo, a filosofia e a ciência se enquadrariam como estratégias fisiológicas para a alavancagem e para a consumação da vontade de poder de seus filósofos e cientistas, e não como estágios superiores e mais dignos de existência, como apontava Platão e outros pensadores. Essa não é nenhuma novidade dentro da filosofia de maturidade nietzschiana expressada a partir de Além de bem e mal, cujo impulso ao conhecimento e ao desconhecimento seria “[...] como um simples instrumento" (NIETZSCHE, BM, $\$ 6$ [2005, p. 13]), constantemente mobilizado e refinado para galgar melhores posiçóes sociais ou quaisquer outras formas de poder.

Mas pensar tal situação sob a ótica da vaidade, ainda mais em obras anteriores, como em Humano, demasiado humano, não apenas é um cenário novo; é, sobretudo, a abertura de horizontes, quiçá, inéditos - embora incertos e perigosos. Afinal, também nossas teses e dissertaçóes, também nossos livros e projetos de pesquisa, também este texto comporia a estética da moralidade indicada por Toledo (2021)? Os baluartes mais excelsos da ciência seriam, no limite, um produto da vaidade humana disposta dramaticamente aos olhos de deuses e valores que existem apenas em nossa imaginação? Se sequer pensarmos em pincelar um "sim" rascunhado para tal pergunta, então, como sairíamos do imbróglio constante de que toda a justificativa para nossas açóes seja apenas uma sofisticada retórica para encobrir nosso egoísmo? 


\section{REFERÊNCIAS}

NIETZSCHE, F. Genealogia da moral. São Paulo: Companhia das Letras, 1998.

NIETZSCHE, F. Além do bem e do mal. São Paulo: Companhia das Letras, 2005.

TOLEDO, R. O. Uma questão de vaidade: relações entre Nietzsche e Mandeville. Trans/ Form/Açáo: revista de filosofia da Unesp, v. 44, n. 1, p. 357-380, 2021. 